\title{
Evaluating in-situ thermal transmittance measurement to analyze devia- tions between actual house thermal performance and modelled one by means of energy simulation software
}

\author{
Estudio de la medición de la transmitancia térmica in situ para analizar desviaciones entre el com- \\ portamiento térmico real de una vivienda y el modelado mediante software de simulación ener- \\ gética
}

Fahimeh Rezvani (Main Author)

University of Zaragoza - CIRCE Research Institute

Maria de Luna 5, 50018 Zaragoza, Aragon (Spain)

713475@unizar.es

Ignacio Zabalza Bribián (Corresponding Author)

University of Zaragoza - Department of Mechanical Engineering and CIRCE Research Institute

Maria de Luna 5, 50018 Zaragoza, Aragon (Spain)

izabal@unizar.es

Manuscript Code: 1301

Date of Acceptance/Reception: 30.07.2019/22.01.2019

DOI: 10.7764/RDLC.18.2.311

\begin{abstract}
Energy diagnosis and check of the energy performance of traditional houses are becoming urgent and essential to achieving energy saving in the residential sector. The paper presents the results of experimental studies focused on the enhancement of the methods to assess the energy efficiency in traditional houses. It is focused on U-value as an indicator of thermal energy efficiency of traditional houses and involves in-situ measurement and the subsequent comparison with $\mathrm{U}$-values calculated by a software tool. The method has been performed on thirteen walls made of stone, brick, solid mud and mixed materials. It has been concluded that in the case of masonries, the differences between the standards and in-situ measurement $U$ values varies considerably from $8 \%$ to $23.5 \%$. Besides, these differences are within a range of $4.7 \%$ to $12.8 \%$ in the brick construction houses, due to the different thermal conductivity of brick materials.
\end{abstract}

Keywords: In-situ measurement, thermal transmittance, heat transfer coefficient (U-value), building energy performance simulation, traditional houses.

Resumen

El diagnóstico energético y el control del comportamiento energético de las casas tradicionales es cada vez más urgente e importante para conseguir ahorrar energía en el sector residencial. El artículo presenta los resultados de estudios experimentales enfocados a la mejora de los métodos para evaluar la eficiencia energética en las casas tradicionales. Se centra en el valor U como un indicador de la eficiencia energética térmica de las casas tradicionales e implica la medición in situ y la posterior comparación con los valores U calculados por medio de una herramienta computacional. El método se ha aplicado en trece muros de piedra, ladrillo, adobe sólido y materiales mixtos. Se concluye que en el caso de las mamposterías, las diferencias entre los valores $U$ calculados y las mediciones in situ varían considerablemente entre el $8 \%$ y el 23,5\%. Además, estas diferencias están dentro del rango del $4,7 \%$ al $12,8 \%$ en las casas construidas con ladrillo, debido a la diferente conductividad térmica de los ladrillos.

Palabras clave: Medición in situ, transmitancia térmica, coeficiente de transferencia de calor (U), simulación del comportamiento energético de edificios, casas tradicionales.

Introduction

The European Commission is committed to cutting $\mathrm{CO}_{2}$ emissions by $80 \%$ relative to 1990 levels by 2050. In line with the above, the European Directive 2010/31/EU establishes that all new buildings constructed in the EU from 2020 onwards should be nearly zero-energy buildings, promoting the thermal envelope improvement, the use of high-efficiency energy equipment and renewable technologies (Directive, 2002; Recast, 2010). This process will involve a higher acceleration of the enhancement of energy performance of the houses, as well as the existing dwelling. In this sense, energy diagnosis of traditional houses is becoming urgent and essential for energy saving. The main ways of heat transfer: conduction, convection, and radiation can reduce through appropriate construction techniques and materials selection. The increasing attention to energy savings in the building sector has led to more and more performing walls characterised by shallow values of thermal transmittance (Asdrubali, D’Alessandro, Baldinelli, \& Bianchi, 2014). Evaluation of in-situ measurement of the thermal transmittance becomes essential in high energy performing houses (Berardi, 2013). 
Regards to the energy balance of the houses, the heat transmission losses in the opaque walls are one of the most critical issues (UNI EN ISO 13790, 2008) (Cordero, García-Santos, \& Overend, 2015). Estimate the thermal efficiency of the opaque elements faces the difficulties of lack of appropriate data for simulating the behaviour of energy building with dynamic or static software. U-value is the most significant factor in determining the thermal efficiency of a house envelope, also subsequently, the overall energy efficiency of a house (Adhikari, 2011). Typically, the wall also constitutes the most major surface of the opaque element; The use phase involves the higher energy consumption of a building, which strongly depends on the U-values of the thermal envelope (Asdrubali et al., 2013). Besides, in the UK, houses are responsible for $48 \%$ of national energy consumption (Wang, Gwilliam, \& Jones, 2009). An accurate evaluation of the performance of building elements, determined through the heat transmission, is necessary to estimate the annual energy consumption (Evangelisti, Battista, Guattari, Basilicata, \& de Lieto Vollaro, 2014; Vollaro et al., 2015). For all these reasons, this paper is focused on the thermal transmission assessment of walls.

$U$-values are used to describe the thermal performance of house elements, and subsequently, the overall energy performance of dwellings. Commonly, U-values are calculated with readily available software rather than measured in-situ (Gorgolewski, 2007). Such measurements are carried out to show compliance with house standards requirements for new dwellings, and for conversions of existing stocks, before construction or conversion.

The U-value was measured according to the conventional moving technique that is described in ISO 9869-1 (ISO, 2014) as the rate of heat flow rate in the steady-state divided by the zone and the difference temperature between each side of the wall. The average of these calculations (taken over an extended period) represents the actual U-value of a building envelope. According to ISO 9869-1, it is essential to measure a wall at least $72 \mathrm{~h}$ because a wall has a thermal mass that enables it to store and release the heat (Baldinelli, 2010; Nardi, Sfarra, \& Ambrosini, 2014). However, Adhikari et al. 2012 (Adhikari, Lucchi, \& Pracchi, 2012), mentioned that the $72 \mathrm{~h}$ of monitoring period is insufficient for the traditional walls and suggested it is better to conduct the test for 90 hours, as the rise of the length of the time in the high thick walls enhance the final result. In addition, the interior temperature should be kept as stable as possible during the measurement to decrease the effect of the thermal capacity of the house elements. Furthermore, the frequency should preferably last a multiple of 24 hours. When the difference between the interior temperature and the outside temperature is too small, the measurement results become unreliable. Therefore, a minimum temperature difference of roughly $5^{\circ} \mathrm{C}$ degrees over the whole measurement time is advised; it means that an assessment of a wall cannot be made during the summer months. For analysing opaque surfaces, energy software modelling can model the heat transfer across walls. It suggests to stratigraphy composed of homogeneous elements. When dealing with inhomogeneous elements, possibly containing hollow bricks, the wall's thermal transmittance evaluate using an effective conductivity (del Coz Díaz, Nieto, Biempica, \& Gero, 2007). However, to verify the theoretical model effectiveness, a comparison with in-situ measurements is needed.

The knowledge of energy behaviour of traditional houses has not yet been improved in an appropriate way. Also, there are not enough experimental data related to the traditional constructive solutions. Wall efficiency depends on the thermal conductivity of each layer constituting the wall which provides data about how heat flows through the components, and the heat capacity of the layers, that is related to physical heat storage. Overall performance depends on thickness, material type, and mass density of each layer. Currently, there are several techniques to obtain in-situ U-values (Albatici \& Tonelli, 2010; Desogus, Mura, \& Ricciu, 2011; Fokaides \& Kalogirou, 2011; Peng \& Wu, 2008). Some are based on the measurement of the heat flux (Cabeza et al., 2010; ISO, 1994; Zarr, 2001). Although the thermal transmittance of opaque walls can be measured by laboratory tests ( UNI EN 1934, 2000), it is also valuable to assess it in real conditions and compare the U-values measured with the U-values calculated using standard tools (Wakili \& Tanner, 2003).

ISO-9869-1 provides a clear guideline to measure U-values under a non-steady state. The U-values measurement techniques in the laboratory are sort of mature. Many standards, such as ISO (ISO 8301, 1991) (ISO 8302, 1991; ISO $8990,1994)$ and ASTM ( ASTM C518-17, 2017), have been regulated since 1990. The calibrated hot box technique requires to use a standard wall to calibrate the boundary heat loss of the hot box under the specific environment. This technique is complex and it is very difficult to calibrate the boundary heat loss exactly (Asdrubali \& Baldinelli, 2011).

The hot box-heat flow meter technique characterizes the indoor and outdoor air temperature difference. So, the hot box-heat flow meter technique is used only in heated houses in winter or air-conditioned houses in summer. This technique depends on air-conditioning \& heating equipment and seasons so, it is difficult to reach the requirement difference temperature (Cesaratto \& De Carli, 2013). The guard hot box technique is not limited by outside and inside air temperature environment, but it needs many measurement types of equipment, for example, the guard boxes and the metering box that is big (Asdrubali \& Baldinelli, 2011). It just suits some special houses. 
The simple hot box-heat flow meter technique creates a rather stable thermal environment by the simple hot box, it creates a difference temperature by the heating function and the box is always installed on the higher temperature side. In this technique, there are a lot of difficulties.

Infrared thermography method is a reliable technique to analyse house elements, it utilizes the emitted infrared radiation from elements. IR camera is able to get the temperature of an element by capturing its emitted infrared radiation as the radiation is a function of the temperature. This method is important when considering its functions in giving surface temperature distributions (Fokaides \& Kalogirou, 2011).

The thermometric method is one of the most used methods in Spain. There are no studies about the viability of this method. However, there are no standards to develop the method, apart from specifications provided by the equipment's manufacturers (KIMO Instruments, 2010; Testo AG, 2014). This method comprises the measurement of outside and inside air temperatures as well as the temperature of the inside wall, but the heat flux is not calculated. The obtained thermal transmittance value in this method can be non-representative because it is a simple theoretical method and in-situ measurements with a simple theoretical can cause metrological problems that lead to atypical values with considerable percentages of uncertainty (Ficco, Iannetta, Ianniello, Alfano, \& Dell'Isola, 2015).

The primary objective of the study is to assess the actual thermal performance of traditional house components to guide energy efficiency assessments. Also, it aims to present the measurement and analysis procedures used to determine the in-situ U-values. Another objective of the paper is to assess the suitability of energy simulation software to estimate the U-values of traditional construction build-up. Such measurement may be used as part of a thermal performance assessment of the traditional house, for instance, to aid in the selection of refurbishment choices. The paper firstly describes the process for in-situ heat flux calculations; then it outlines the measured houses, building components, analysis and conversion intro U-values. In-situ U-value measurements were made mainly in walls. The primary focus of the studies was on walls constructed with a range of materials and techniques; the building elements were measured, including in existing surface finishes. All the U-value measurements were based on the heat flux method, which uses data of a heat flux sensor and two temperature sensors.

This paper is focused on U-values as an indicator of thermal efficiency and involves in-situ measurement and the subsequent comparison with theoretical U-values calculated by software tools. U-values are usually calculated with standard ISO 6946. The suitability of such software when used to evaluate traditional houses requires more detailed research and analysis (Baker, 2011). The results will help professionals and assessors of energy home performance to make better known and more balanced decisions when assessing and progressing the energy efficiency of old homes. The unique contribution of this paper is the in-situ U-value measured using GreenTeg software that use the data logger to obtain results of the heat flux, the software compatible with standards ISO 9869-1 and ASTM C1046-95 \& ASTM C1155-95 (ASTM, 2013a; ASTM, 2013b) and the subsequent comparison with theoretical U-values.

\section{Methodology}

This section describes the work on measuring the thermal transmittance (U-value), through components of traditionally constructed properties. The properties featured in the paper are typical examples of pre-1919 construction in Scotland. All of the houses are of traditional construction (solid walls), and most are constructed from lime-bonded rubble or ashlar stonework, typically 300 to $600 \mathrm{~mm}$ thick, with natural slate or tile roofs, doors and timber windows (Garnier \& Ohmura, 1970).

In this study, in-situ U-value measurement of thirteen walls were carried out. In some cases, measurements are taken for comparison of different wall materials. The exact build-up of the calculated wall often was not known. All homes were occupied except in case 10 and all located in Scotland. The heat flow was directly measured through the house component using heat flux sensors mounted on an internal surface and using temperature sensors inside and outside the dwelling. All measurements were taken in occupied properties except for case 10 and included external, and interior wall finishes.

The measurements have to perform in the selected wall where heat flow is one-dimensional. One-dimensional heat flow demonstrates the flowing of heat in one plane of the wall and out the other face; where the cross-sectional zone of the wall in the heat flow direction is stable. Those walls are selected by an infra-red camera that generally is used to locate places with much different temperature and inhomogeneous components; moreover, it assists in doing not locate the sensors on the cold bridges.

Where possible a North face or protective wall was selected to avoid direct solar radiation (Garnier \& Ohmura, 1970), 
so solar radiation could not affect. It is better to avoid measuring in the south wall of a dwelling since the thermal storage capacity of the wall should not underestimate. Moreover, it is better to cover the temperature sensor to block any direct sunlight (e.g., with aluminium foil) (Evangelisti, Guattari, Gori, \& Vollaro, 2015). Measurements had no impact on the daily routines of building occupants because the measurement setup was rather small. If the sensors are located correctly, they will not bother any house resident. To increment the accuracy of the obtained data dwelling occupants, the interior temperature was kept as stable as possible (e.g., by limiting the opening of the window or not switching the radiator off during the night).

\section{In-situ measurement equipment and process}

Each of the measurement setups included:

- 1 x Heat flux sensor gSKIN - XO 67 7C (30mm x 30mm) (Technical specifications can be found in https://www.omniinstruments.co.uk/fileuploader/download/download/?d=0\&file=custom\%2Fupload\%2F5243.pdf).

- 2 x Temperature sensors.

- 1 x Data logger gSKIN ${ }^{\oplus}$ DLOG-4231 (Technical specifications can be found in https://shop.greenteg.com/wp-content/uploads/gSKIN_DLOG_Datasheet_v3.10.pdf) with an adjustable calculating frequency that facilitates the automatic recording of heat flux through the house component, interior, and exterior temperatures.

For each configuration, a heat flux sensor was mounted on the inside of the wall using regular adhesive tapes. One of the temperature sensors was mounted near the heat flux sensor. The second temperature sensor was installed in correspondence of the other surface temperature positioned inside.

During in-situ calculations, the boundary conditions (solar radiation, temperature, and wind velocity) changed with time (Baker, 2011). Therefore the heat flux sensor was covered with aluminium foil to minimise the impact of the solar radiation on the measurement outcomes. The whole setup was connected to the data logger, who recorded the heat flux $\left(\phi_{\mathrm{j}}\right)$ and inside surface temperature $\left(\mathrm{T}_{\mathrm{ij}}\right)$ and outside surface temperature $\left(\mathrm{T}_{\mathrm{oj}}\right)$ simultaneously at a sampling rate of 1 sample per 5 minutes. Sensors place were chosen to avoid the probable thermal bridge, locations nearby to corners and windows. The heat flow sensor was ideally placed about halfway between the edges and window, and ceiling and floor. Figure 1 illustrates the in-situ measurement graphically.

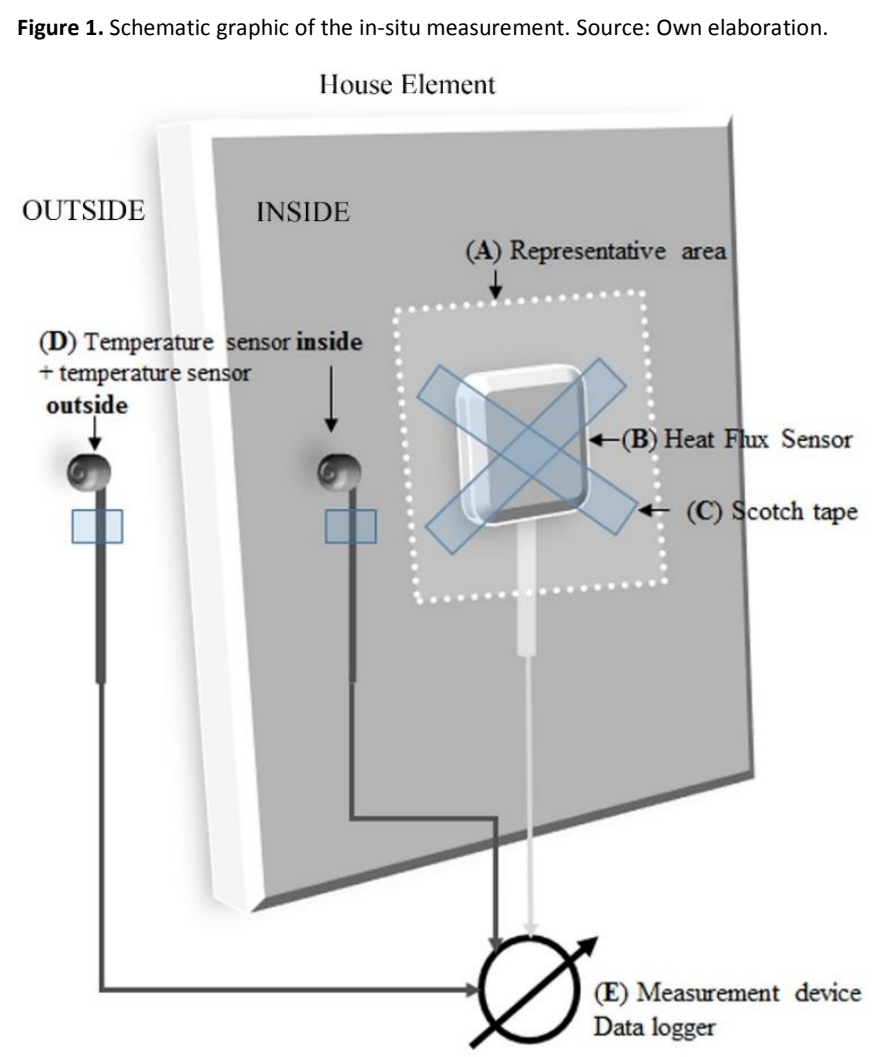

Data acquisition (according to Standard ISO 9869-1: The calculation duration considered was 90 hours. The measurement was ended when the $U$-value did not deviate by more than $\pm 5 \%$ of the value achieved $24 \mathrm{~h}$ earlier (automatically 
calculated by GreenTeg software). Typical recording frequency of the data logger (E) is one data point per 5 minutes. The U-value calculation through experimental data is, in general, performed using the progressive average method.

Use the data logger (E) to obtain results of the heat flux: the flux sensor was connected to the measurement tool and the output voltage $V$ was recorded. Then, the heat flux $\phi$ was calculated considering the sensor-specific sensitivity $S$, as shown in the equation [1].

$$
\phi=\frac{V}{S}
$$

Where $\phi$ is the heat flux $\left(\mathrm{W} / \mathrm{m}^{2}\right), \mathrm{V}$ is the measured voltage $(\mu \mathrm{V})$, and $\mathrm{S}$ is the sensor-specific sensitivity in $\left(\mu \mathrm{V} /\left(\mathrm{W} / \mathrm{m}^{2}\right)\right)$. Then, the $U$-Value $\left(\mathrm{W} / / \mathrm{m}^{2} \mathrm{~K}\right)$ was calculated using the equation [2].

$$
U-\text { value }=\frac{\sum_{j=1}^{n} \phi_{j}}{\sum_{j=1}^{n}\left(T_{i j}-T_{o j}\right)}
$$

where $T_{o j}$ is the outside surface temperature $(K) ; T_{i j}$ is the inside surface temperature $(K)$, and $\phi_{j}$ is the heat flux $\left(W / m^{2}\right)$ in each $\mathrm{j}$ instant, from $\mathrm{j}=1$ ton.

\section{Theoretical U-value calculations}

The theoretical U-values of the house components are also calculated according to the standard ISO 6946 by using a software tool. Energy simulation software tools for buildings have had developments over the years (Crawley et al., 2001). Currently, there are different tools with different levels of complexity and response to different variables. Some examples are DesignBuilder (EnergyPlus), ESP-r (Energy Simulation Software tool), IES-VE (Integrated Environmental Solutions-Virtual Environment) and TRNSYS.

For this study, DesignBuilder U-value Calculator tool was selected to calculate the U-values of the house components measured. It was deemed an appropriate tool for the $U$-value comparison calculations since its calculations are based on the standard ISO 6946 (Anderson, 2006). Also, DesignBuilder is a thermal simulation program that enables the energy modelling and analysis of any building (Wasilowski \& Reinhart, 2009).

In order to calculate the U-value, a wall stratigraphy of the house and the materials thermal conductivity values are required. In this study, the building materials database of DesignBuilder, which includes default thermal conductivity values, was considered. Standard ISO 9869-1 provides thermal conductivity values of the primary construction materials when it is not possible to get direct information from a database or a product data-sheet. Starting from this information, it is possible to choose among many categories for each material, characterised by different thermal properties. According to ISO 6946 the theoretical U-value can be calculated using equation 3:

$$
U-\text { value }=\frac{1}{R_{t}}=\frac{1}{R_{\text {si }}+R_{\text {layers }}+R_{\text {se }}}[3]
$$

Where $R_{t}$ is the total thermal resistance of the house component considered $\left(m^{2} K / W\right)$, Rlayers is the total thermal resistance of the component $\left(\mathrm{m}^{2} \mathrm{~K} / \mathrm{W}\right)$, whereas $R_{s i}$ and $R_{s e}$ are the convective thermal resistance of the inside and outside surfaces of the component $\left(\mathrm{m}^{2} \mathrm{~K} / \mathrm{W}\right)$. In this study, a value of $0.13 \mathrm{~m}^{2} \mathrm{~K} / \mathrm{W}$ and $0.04 \mathrm{~m}^{2} \mathrm{~K} / \mathrm{W}$ was taken for $R_{s i}$ and $R_{s e}$ respectively. Moreover, equation 4 allows to calculate $R_{\text {layers }}\left(m^{2} K / W\right)$ :

$$
R_{\text {layers }}=\sum_{k=1}^{m} R_{k}[4]
$$

Where $R_{k}$ is the thermal resistance of the layer $k$ of the component $\left(m^{2} K / W\right)$, from $k=1$ to $m$ layers. $R_{k}\left(m^{2} K / W\right)$ can be calculated using equation 5 if the layer is solid, or equation 6 if the layer is a fluid (e.g. air gap):

$$
\begin{array}{ll}
R_{k}=\frac{e_{k}}{\lambda_{k}} & \text { [5] } \\
R_{k}=\frac{1}{h_{k}} & {[6]}
\end{array}
$$

Where $e_{k}$ is the thickness of the layer $k(m), \lambda_{k}$ is the thermal conductivity of the layer $k(\mathrm{~W} / \mathrm{mK})$, and $h_{k}$ is the convective heat transfer coefficient of the layer $k\left(\mathrm{~W} / \mathrm{m}^{2} \mathrm{~K}\right)$ of the component, from $\mathrm{k}=1$ to $\mathrm{m}$ layers. 


\section{Case studies}

Twelve properties throughout Scotland were visited for the experimental measurements. Houses with different kinds of materials, all of them constructed pre-1919 with traditional construction techniques, were chosen for this analysis. Eight of them are located in Edinburgh, case 7 located in Dalkeith, case 9 in Lauder, case 10 in Bonnyrigg and case 11 in Duns. Thirteen walls were measured; just two walls were insulated.

U-values of walls were measured reliably via heat flux measurements. Different types of walls, varying widely in thermal performance, can be assessed accurately. However, concerns raised about the influence of external conditions on the outcome of the measurement. It is critical since heat flux measurements are performed in an occupied building in which stable conditions are challenging to reach. The fluctuation of inside temperature has a significant effect on the measured heat flux and the U-value. However, it is advisable to keep the interior temperature constant to reach a reliable U-value. The impact of the outside temperature on the heat flux can be substantial. Therefore a calculation would last 24 hours preferably, by taking into account the daily change in temperature.

Traditionally constructed walls in Scotland are usually 400 to $600 \mathrm{~mm}$ thick and built with stone (of differing rock types) either rubble or dressed stones bedded in lime mortar with a rubble mortar core. The wall is often finished internally with lath and plaster lining with a 10 to $30 \mathrm{~mm}$ air gap between the lining and stone wall. In some areas, walls are plastered directly onto the rock, on the hard, although this is less common in most residential buildings. Such stone walls are not homogenous in their build-up, but consist of inner and outer stone leaves with the centre of the barrier being pack with smaller stone and mortar. The details of the measured elements are listed in Table 1.

Table 1. Detail of the measured elements*. Source: Own elaboration.

\begin{tabular}{|c|c|c|c|}
\hline Wall materials & $\begin{array}{c}\text { Thickness } \\
(\mathrm{mm})\end{array}$ & $\begin{array}{c}\text { Thermal conductivity } \\
(\mathrm{W} / \mathrm{mK})\end{array}$ & $\begin{array}{c}\text { Year of construction (re- } \\
\text { furbishment) }\end{array}$ \\
\hline Case 1 & & & $1915(1984)$ \\
\hline Brick & 80 & 0.84 & \\
\hline Air gap & 10 & - & \\
\hline Fibreglass insulation & 20 & 0.036 & \\
\hline Brick & 80 & 1.1 & \\
\hline Plaster of hard & 15 & 0.25 & \\
\hline Total thickness (mm) & 220 & & \\
\hline Case 2 & & & 1910 \\
\hline Cement sand render & 10 & 1.50 & \\
\hline Sandstone & 120 & 4.20 & \\
\hline Fibreglass insulation & 20 & 0.04 & \\
\hline Sandstone & 250 & 5.00 & \\
\hline Air gap & 5 & - & \\
\hline Gypsum plasterboard & 10 & 0.70 & \\
\hline Total thickness (mm) & 415 & & \\
\hline Case 3 & & & 1902 \\
\hline Gypsum plastering & 25 & 0.40 & \\
\hline Tuff stone & 500 & 3.50 & \\
\hline Air gap & 5 & - & \\
\hline Gypsum plasterboard & 20 & 0.50 & \\
\hline Total thickness (mm) & 550 & & \\
\hline Case 4 & & & 1891 \\
\hline Ashlar & 100 & 1.50 & \\
\hline Air gap & 10 & - & \\
\hline Blond sandstone & 400 & 5.00 & \\
\hline Plaster on hard & 20 & 0.16 & \\
\hline Total thickness (mm) & 530 & & \\
\hline Case 5 & & & 1885 \\
\hline Ashlar & 200 & 1.83 & \\
\hline Blond sandstone & 400 & 5.00 & \\
\hline Air gap & 10 & - & \\
\hline Plaster on laths & 20 & 0.4 & \\
\hline Total thickness (mm) & 630 & & \\
\hline
\end{tabular}




\begin{tabular}{|c|c|c|c|}
\hline Case 6 & & & 1877 \\
\hline Squared rubble & 130 & 1.74 & \\
\hline Locharbriggs sandstone & 450 & 3.70 & \\
\hline Air gap & 5 & - & \\
\hline Plaster on laths & 15 & 0.6 & \\
\hline Total thickness (mm) & 600 & & \\
\hline Case 7a (uninsulated wall) & & & 1866(1982) \\
\hline Brick & 200 & 1.10 & \\
\hline Sandstone & 350 & 5.00 & \\
\hline Air gap & 25 & - & \\
\hline Plaster on laths & 11 & 0.88 & \\
\hline Total thickness (mm) & 590 & & \\
\hline Case 7b (insulated wall) & & & 1866 \\
\hline Brick & 100 & 0.84 & \\
\hline Fibreglass insulation & 80 & 0.036 & \\
\hline Brick & 150 & 0.3 & \\
\hline Air gap & 5 & - & \\
\hline Plaster on laths & 13 & 0.42 & \\
\hline Total thickness (mm) & 350 & & \\
\hline Case 8 & & & 1857 \\
\hline Coursed Rubble & 200 & 1.50 & \\
\hline Sandstone & 350 & 1.83 & \\
\hline Plaster on Hard & 25 & 0.4 & \\
\hline Total Thickness (mm) & 575 & & \\
\hline Case 9 & & & 1853 \\
\hline Rubble & 250 & 1.83 & \\
\hline Torridonian sandstone & 300 & 2.3 & \\
\hline Air gap & 7 & - & \\
\hline Plaster on laths & 12 & 0.75 & \\
\hline Total thickness (mm) & 570 & & \\
\hline Case 10 & & & 1848 \\
\hline Squared rubble & 280 & 1.50 & \\
\hline Kemnay sandstone & 350 & 3.2 & \\
\hline Plaster on hard & 25 & 0.3 & \\
\hline Total thickness (mm) & 655 & & \\
\hline Case 11 & & & 1846 \\
\hline Clay harling & 200 & 2.1 & \\
\hline Solid mud & 300 & 2.5 & \\
\hline Air gap & 10 & - & \\
\hline Timber lining & 10 & 0.25 & \\
\hline Total thickness (mm) & 520 & & \\
\hline Case 12 & & & 1794 \\
\hline Squared rubble & 120 & 3.40 & \\
\hline Craigleith sandstone & 520 & 4.50 & \\
\hline Air gap & 5 & - & \\
\hline Plasterboard & 11 & 0.90 & \\
\hline Total thickness (mm) & 685 & & \\
\hline
\end{tabular}

*The values of this table have been extracted from EnergyPlus library.

The results of the in-situ U-value measurements and the comparable calculated values are summarised in Table 2 and Figure 2. 
Table 2. Summary of results. Source: Own elaboration.

\begin{tabular}{|c|c|c|c|c|c|}
\hline $\begin{array}{l}\text { Descrip- } \\
\text { tion }\end{array}$ & $\begin{array}{l}\text { Calculated U- } \\
\text { Value }\left(\mathrm{W} / \mathrm{m}^{2} \mathrm{~K}\right)\end{array}$ & $\begin{array}{l}\text { Measured U-Value } \\
\qquad\left(\mathrm{W} / \mathrm{m}^{2} \mathrm{~K}\right)\end{array}$ & Difference (\%) & Main material & $\begin{array}{l}\text { Insulation or } \\
\text { air gap }\end{array}$ \\
\hline Case 1 & 0.906 & 0.79 & -12.80 & Brick & Both \\
\hline Case 2 & 1.137 & 0.89 & -21.72 & Sand & Both \\
\hline Case 3 & 2.1 & 1.93 & -8.09 & Sand & Air gap \\
\hline Case 4 & 1.717 & 1.39 & -18.46 & Sand & Air gap \\
\hline Case 5 & 1.788 & 1.61 & -9.95 & Sand & Air gap \\
\hline Case 6 & 2.00 & 1.82 & -9.00 & Sand & Air gap \\
\hline Case 7a & 1.602 & 1.43 & -10.73 & Brick/sand & Air gap \\
\hline Case $7 b$ & 0.317 & 0.302 & -4.73 & Brick & Both \\
\hline Case 8 & 1.8 & 1.69 & -6.11 & Sand & - \\
\hline Case 9 & 1.715 & 1.44 & -16.03 & Sand & Air gap \\
\hline Case 10 & 1.896 & 1.45 & -23.52 & Sand & - \\
\hline Case 11 & 1.738 & 0.999 & -42.52 & Solid mud & Air gap \\
\hline Case 12 & 2.273 & 2.04 & -10.25 & Sand & Air gap \\
\hline
\end{tabular}

Figure 2. The difference between calculated and measured U-value $\left(\mathrm{W} / \mathrm{m}^{2} \mathrm{~K}\right)$. Source: Own elaboration.

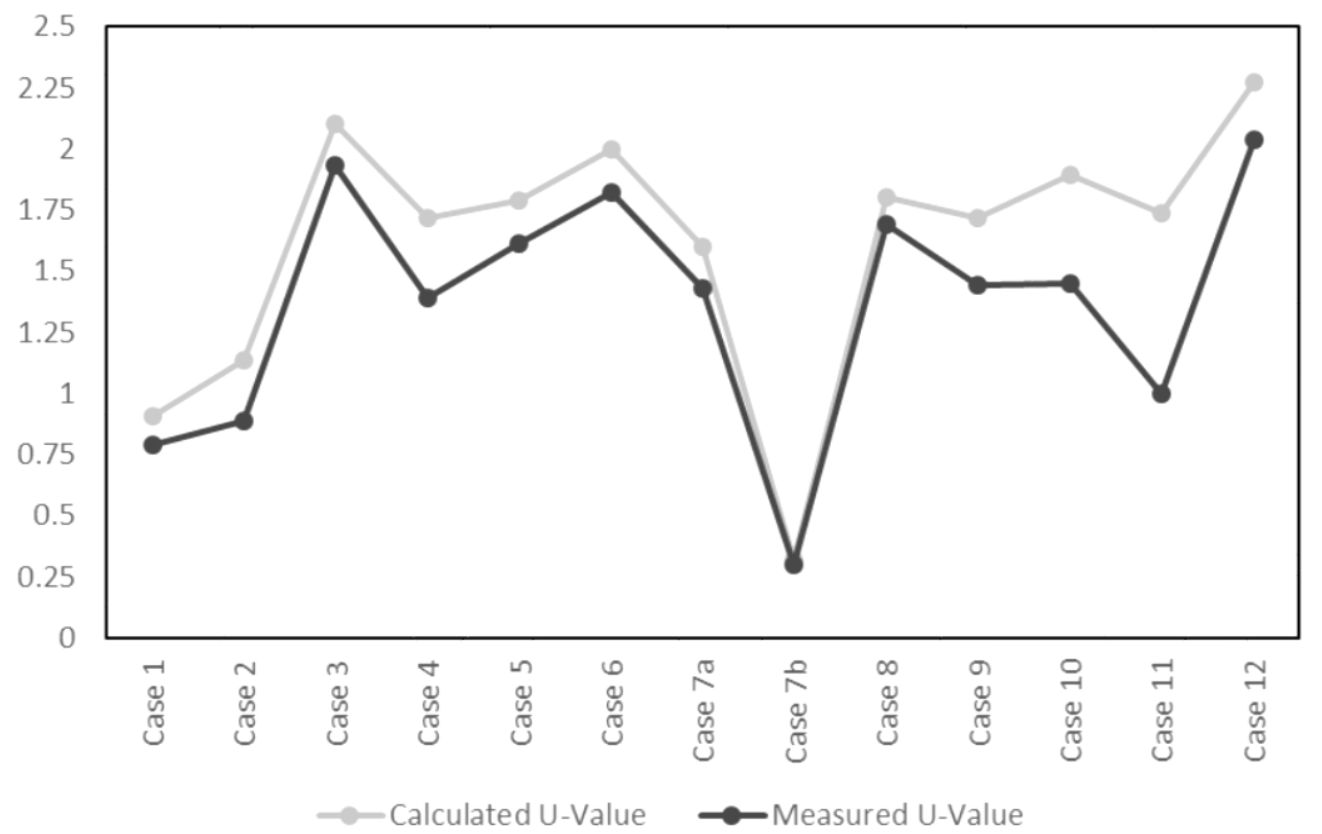

The results of the measurements performed in the twelve cases studies are lower than the comparable calculated appraisement of the thermal transmittance.

The mismatch of case $7 b$ (wall insulated) is the smallest one. U-value calculations for case $7 b$, the brick cavity wall construction with better-defined build-ups gave closer agreement to the in-situ measurement results. This acceptable achievement is related to the material with insulation layers; the insulating elements seem to have thermal properties similar to those declared by the manufacturers. The thermal conductivity of hollow brick, according to the standard, is a function of thickness. Hence, the variation in the corresponding U-value is reduced. 
Case 2, 10, 11 and almost 4 have significant differences between the calculated U-value and in-situ U-value measurement, ISO 9869-1 provide some reasons for significant differences (>20\%) between values. For case 2, probably the reason is that the values assumed for the thermal conductivities are not the true values; especially the insulating ones, the house built in 1910 with insulation layer, presumably the fibreglass insulation with thermal conductivity of 0.04 $\mathrm{W} / \mathrm{mK}$ is not a true value or maybe the thickness of the insulation layer is not correct; the other reason is the surface resistance is not precise because of poorly insulated elements. About case 4, perhaps a considerable difference contributes to incorrect values for thermal conductivity and thickness of Ashlar materials, another reason is that maybe there are phase changes such as moisture, water or freezing.

The good performance of case 11 mainly depends on the thick thermal block with excellent thermal conductivity values as there is no layer of thermal insulation in this case. Besides, in case 11, the difference between the calculated and the measured transmittance values are higher definitely if compared with another thirteen samples studies. An explanation of this mismatch could be because of overestimating the thermal resistance declared by the manufacturer are used in the software U-value calculations. Probably, in this example, the wall is made of different layers that are not detectable by visual inspection. Another possibility is that the solid mud thermal conductivity value may be significantly different from the one provided by the standard.

Then, the case 10 is characterised by the second-highest percentage difference $(-23.5 \%)$. The reason is that the house was the first one that was measured and was unoccupied so, too small differences between the indoor and outside temperatures resulted in increased measurements uncertainty. Another possibility is that the thermal conductivity value of Kemnay sandstone may be considerably different from the one provided (del Coz Díaz et al., 2007). The walls plastered on the hard and with plaster on laths in cases 5, 6. 7 and 8 with the difference between 5-10\% show a result in agreement with the values calculated by software better than the timber lining finishes in case 11 with a difference of $42.52 \%$, which shows poor agreement with the measured U-values.

Such different thermal characteristics imply several of the thermal transmittance values, which can influence the design phase of a modern construction significantly. On the other hand, reliable data about every single layer of the analysed wall is needed (Evangelisti et al., 2015). In most cases, the stratigraphy is reduced according to the building construction year. In addition, the simplified method to label a home exclusively employs the value of thermal transmittance, neglecting the information about the mass density and specific heat capacity of the materials constituting the walls. In these case studies, measurements results and the thermal transmittance has been calculated through the elements provided by the ISO 9869-1.

There are several studies on in-situ U-value measurement, such as Baker (2008), which have studied about 70 in-situ Uvalue measurements of walls, roofs and a floor at 15 properties over three heating seasons between November 2007 and March 2010, Currie, Williamson, \& Stinson (2013), which have worked on 29 in-situ U-value measurement of house elements at 10 houses, and Gaspar, Casals, \& Gangolells (2016), which have investigated about 3 walls in 3 different buildings. All of them illustrated in a similar way that the value of U-value could vary considerably from one to another house, also within one house itself. In both conditions, the calculation methods and standards tend to overestimate the $\mathrm{U}$-values compared to the in-situ measurements results.

\section{Internal finishes}

Three kinds of internal wall finishes were included in the measurements:

- Plaster on laths.

- Timber lining.

- Plastered on the hard.

Except for the plaster on the hard, all finishes were fixed to studs/battens (made from timber) that then adjusted back to the wall faces. The depth of the studs/battens could vary, typical sizes are $26 \mathrm{~mm}$ for plaster on laths finishes.

Walls with interior finishes which incorporate an air-filled cavity (unventilated), such as timber lining and plaster on laths, have lower U-values than walls of the same thickness finished with plaster on hard. It demonstrates the insulating effect of an air cavity behind a plaster on laths and timber lining, as shown in Table 3. In addition, the higher the thermal resistance of timber compared to lime plaster should be considered. 
Table 3. Theoretical effect of air gaps in solid walls. Source: Hulme \& Doran (2014).

\begin{tabular}{ccc}
\hline $\begin{array}{c}\text { Width of the air gap } \\
(\mathrm{mm})\end{array}$ & $\begin{array}{c}\text { Thermal resistance of air } \\
\text { gap }\left(\mathrm{m}^{2} \mathrm{~K} / \mathrm{W}\right)\end{array}$ & $\begin{array}{c}\text { Equivalent thermal } \\
\text { ductivity of air gap }(\mathrm{W} / \mathrm{mK})\end{array}$ \\
\hline 5 & 0.11 & 0.05 \\
10 & 0.15 & 0.07 \\
15 & 0.17 & 0.09 \\
20 & 0.18 & 0.11 \\
50 & 0.18 & 0.38 \\
\hline
\end{tabular}

For instance, where there are no headers bridging the airspace, it is more appropriate to consider the wall as a cavity wall, and where the airspace is spanned by connecting headers, then it is appropriate to find the wall as a solid wall. The air gap in the centre of a solid wall could be interconnected to some extent, which may affect the U-values. Moving current air with these structures can rise the U-values, while static air is likely to diminish U-values.

\section{Conclusions}

To verify the suitability of using the U-value calculation tool with old house components, this study compares the in-situ U-values measured with their equivalent calculated by the software according to ISO 6946 standard. A particular focus of the comparison is the impact of lime and stone core of an old solid stone wall which is not considered in the tool, assuming a homogeneous buildability of masonry throughout the thickness of the wall. The U-values measured in this study were subsequently compared with the calculated U-values using DesignBuilder U-value calculator, to assess the applicability of this tool when used for evaluating traditional building construction since this tool is typically used as an assessment tool for new and existing stock to ensure their adoption with $\mathrm{U}$-value requirement of house standards.

Usually, U-value calculation tools only provide limited baseline data for some traditional buildings materials (e.g., DesignBuilder database presents just two options for stone types: sandstone and granite). Although the modelling of mortar joints in masonry is included in such tools, the modelling of a solid stone wall (i.e., with a centre packed with small stones and mortar) is not considered, and it has to be modelled as a multilayer build-up. The in-situ measurement of U-values is a useful tool which can aid in the assessment of the thermal performance of traditional house materials, particularly where calculation methods may suffer from the lack of knowledge of the traditional buildups and the thermal properties of conventional materials. As shown in the study, calculated values are usually higher than the in-situ measured ones. The brick wall construction gave closer agreement to the in-situ measurement results. The acceptable achievement is related to the material with insulation layers that have thermal properties similar to those declared by the manufacturers. Moreover, the walls plastered on the hard and with plaster on laths show a result in agreement with the values calculated by software better than the timber lining finishes.

The in-situ measurements permit to calibrate the thermal performance of traditional walls better. The information constitutes a stable base for the correct diagnosis of energy performance in traditional houses, especially for the evaluation of thermal performance through the opaque elements. Besides, the conditions of operative measurement and the characteristics of the element under investigation strongly can impact on the accuracy of the in-situ U-values. Moreover, it is essential to enhance the new energy simulation tools dedicated to traditional houses adding specific databases related to the thermophysical properties of house elements and more appropriate information referred to traditional construction techniques.

Adhikari, R. S. (2011). Energy behaviour in historical buildings: limits and potentials for the project evaluation Proc. PLEA 2011. In 27th International conference on Passive and Low Energy Architecture. Louvain-Ia-Neuve. Belgium (pp. 515-520).

Adhikari, R. S., Lucchi, E., \& Pracchi, V. (2012). Experimental measurements on thermal transmittance of the opaque vertical walls in the historical buildings. In PLEA2012-28th Conference, Opportunities, Limits \& Needs Towards an environmentally responsible architecture.

Albatici, R., \& Tonelli, A. M. (2010). Infrared thermovision technique for the assessment of thermal transmittance value of opaque building elements on site. Energy and Buildings, 42(11), 2177-2183. 
Anderson, B. (2006). Conventions for U-value calculations. Retrieved from https://www.bre.co.uk/filelibrary/pdf/rpts/BR_443_(2006_Edition).pdf.

Asdrubali, F., \& Baldinelli, G. (2011). Thermal transmittance measurements with the hot box method: Calibration, experimental procedures, and uncertainty analyses of three different approaches. Energy and Buildings, 43(7), 1618-1626.

Asdrubali, F., Buratti, C., Cotana, F., Baldinelli, G., Goretti, M., Moretti, E., Rotili, A. (2013). Evaluation of green buildings' overall performance through in situ monitoring and simulations. Energies, 6(12), 6525-6547.

Asdrubali, F., D'Alessandro, F., Baldinelli, G., \& Bianchi, F. (2014). Evaluating in situ thermal transmittances of green buildings masonries-A case study. Case Studies in Construction Materials, 1, 53-59.

ASTM C1046-95 (2013a) Standard practice for in-situ measurement of heat flux and temperature on building envelope components. ASTM International: West Conshohocken PA, USA.

ASTM C1155-95 (2013b) Standard practice for determining thermal resistance of building envelope components from the in-situ data. ASTM International: West Conshohocken PA, USA.

ASTM C518-17 (2017). Standard test method for steady-state thermal transmission properties by means of the heat flow meter apparatus. ASTM International: West Conshohocken PA, USA.

Baker, P. (2008). In situ U-value measurements in traditional buildings: Preliminary results. Historic Scotland, Technical Paper 2, Edinburgh: Historic Scotland.

Baker, P. (2011). U-values and traditional buildings: in situ measurements and their comparisons to calculated values. Historic Scotland Technical Paper 10, Edinburgh: Historic Scotland.

Baldinelli, G. (2010). A methodology for experimental evaluations of Low-E barriers thermal properties: Field tests and comparison with theoretical models. Building and Environment, 45(4), 1016-1024.

Berardi, U. (2013). Clarifying the new interpretations of the concept of sustainable building. Sustainable Cities and Society, 8, 72-78.

Cabeza, L. F., Castell, A., Medrano, M., Martorell, I., Pérez, G., \& Fernández, I. (2010). Experimental study on the performance of insulation materials in Mediterranean construction. Energy and Buildings, 42(5), 630-636.

Cesaratto, P. G., \& De Carli, M. (2013). A measuring campaign of thermal conductance in situ and possible impacts on net energy demand in buildings. Energy and Buildings, 59, 29-36.

Cordero, B., García-Santos, A., \& Overend, M. (2015). Thermal performance of novel frame-integrated unitised curtain wall. Revista de la Construcción, 14(1), 23-31.

Crawley, D. B., Lawrie, L. K., Winkelmann, F. C., Buhl, W. F., Huang, Y. J., Pedersen, C. O., Witte, M. J. (2001). EnergyPlus: creating a new-generation building energy simulation program. Energy and Buildings, 33(4), 319-331.

Currie, J., Williamson, J. B., \& Stinson, J. (2013). Monitoring thermal upgrades to ten traditional properties. Historic Scotland, Technical Paper 2, Edinburgh: Historic Scotland.

Coz Díaz, J. J., Nieto, P. J. G., Biempica, C. B., \& Gero, M. B. P. (2007). Analysis and optimization of the heat-insulating light concrete hollow brick walls design by the finite element method. Applied Thermal Engineering, 27(8), 1445-1456.

Desogus, G., Mura, S., \& Ricciu, R. (2011). Comparing different approaches to in situ measurement of building components thermal resistance. Energy and Buildings, 43(10), 2613-2620.

Directive, E. N. (2002). 91/EC of the European Parliament and of the Council of 16 December 2002 on the energy performance of buildings. Official Journal of the European Communities, 4(2003), L1.

Evangelisti, L., Battista, G., Guattari, C., Basilicata, C., \& de Lieto Vollaro, R. (2014). Influence of the thermal inertia in the European simplified procedures for the assessment of buildings' energy performance. Sustainability, 6(7), 4514-4524.

Evangelisti, L., Guattari, C., Gori, P., \& Vollaro, R. D. L. (2015). In situ thermal transmittance measurements for investigating differences between wall models and actual building performance. Sustainability, 7(8), 10388-10398.

Ficco, G., lannetta, F., lanniello, E., Alfano, F. R. d'Ambrosio, \& Dell'Isola, M. (2015). U-value in situ measurement for energy diagnosis of existing buildings. Energy and Buildings, 104, 108-121.

Fokaides, P. A., \& Kalogirou, S. A. (2011). Application of infrared thermography for the determination of the overall heat transfer coefficient (U-Value) in building envelopes. Applied Energy, 88(12), 4358-4365.

Garnier, B. J., \& Ohmura, A. (1970). The evaluation of surface variations in solar radiation income. Solar Energy, 13(1), 21-34.

Gaspar, K., Casals, M., \& Gangolells, M. (2016). A comparison of standardized calculation methods for in situ measurements of façades U-value. Energy and Buildings, 130, 592-599.

Gorgolewski, M. (2007). Developing a simplified method of calculating U-values in light steel framing. Building and Environment, 42(1), 230-236.

Hulme, J., \& Doran, S. (2014). BRE Report In-situ measurements of wall U-values in English housing. BRE, Watford.

ISO 8301 (1991) Thermal insulation-determination of steady-state thermal resistance and related properties - Heat flow meter apparatus. International Standards Organization, Geneva, Switzerland.

ISO 8302 (1991). Thermal insulation-determination of steady-state thermal resistance and related properties-guarded hot plate apparatus. International Standards Organization, Geneva, Switzerland. 
ISO 8990 (1994). Thermal insulation-determination of steady-state thermal resistance and related properties-calibrated and guarded hot box. International Standards Organization, Geneva, Switzerland.

ISO 9869-1 (2014). Thermal Insulation-Building Elements-In Situ Measurement of Thermal Resistance and Thermal Transmittance-Calculation Methods. International Organization for Standardization: Geneva, Switzerland.

KIMO Instruments (2010). Determination of U Coefficient; KIMO Instruments: Montpon-Menesterol, France.

Nardi, I., Sfarra, S., \& Ambrosini, D. (2014). Quantitative thermography for the estimation of the U-value: state of the art and a case study. In Journal of Physics: Conference Series 547, 12016). IOP Publishing.

Peng, C., \& Wu, Z. (2008). In situ measuring and evaluating the thermal resistance of building construction. Energy and Buildings, 40(11), $2076-2082$.

Recast, E. (2010). Directive 2010/31/EU of the European Parliament and of the Council of 19 May 2010 on the energy performance of buildings (recast). Official Journal of the European Union, 18(06), 2010.

Testo AG. (2014). U-Value Measurement; Testo AG: Lenzkirch, Germany.

UNI EN ISO 13790 (2008). Energy Performance of Buildings-Calculation of Energy Use for Space Heating and Cooling. Ente Nazionale Italiano di Unificazione: Milan, Italy.

UNI EN 1934 (2000). Thermal performance of buildings-Determination of thermal resistance by hot box method using heat flow meter-Masonry. Ente Nazionale Italiano di Unificazione: Milan, Italy.

Vollaro, R. D. L., Guattari, C., Evangelisti, L., Battista, G., Carnielo, E., \& Gori, P. (2015). Building energy performance analysis: A case study. Energy and Buildings, 87, 87-94.

Wakili, K. G., \& Tanner, C. (2003). U-value of a dried wall made of perforated porous clay bricks: Hot box measurement versus numerical analysis. Energy and Buildings, 35(7), 675-680.

Wang, L., Gwilliam, J., \& Jones, P. (2009). Case study of zero energy house design in UK. Energy and Buildings, 41(11), 1215-1222.

Wasilowski, H. A., \& Reinhart, C. F. (2009). Modelling an existing building in DesignBuilder/EnergyPlus: custom versus default inputs. In Eleventh International IBPSA Conference (pp. 1252-1259).

Zarr, R. R. (2001). A history of testing heat insulators at the national institute of standards and technology. ASHRAE Transactions, $107,661$. 